\title{
PREVENTÓRIO RAINHA DONA AMÉLIA: UM SANATÓRIO PARA CRIANÇAS ENFRAQUECIDAS
}

\author{
Dilene Raimundo do Nascimento \\ Casa de Oswaldo Cruz/Fiocruz
}

\section{RESUMO}

Este artigo pretende examinar as condições da cidade do Rio de Janeiro, seja no que diz respeito à insalubridade da cidade seja em relação às condições de vida e moradia dos seus trabalhadores, que propiciavam a disseminação da tuberculose no final do século XIX e início do XX. Constatando-se a alta incidência da tuberculose nessa época, pretende-se verificar a motivação de criação e o propósito da Liga Brasileira contra a Tuberculose e analisar o seu projeto de assistência à saúde das crianças e sua intervenção disciplinar, que resultou na criação do Preventório Rainha Dona Amélia.

PALAVRAS-CHAVE:Liga Brasileira contra a Tuberculose. História. Assistência à saúde das crianças. Tuberculose. Rio de Janeiro.

\section{DONA AMÉLIA QUEEN REFORMATORY: A SANATORIUM FOR WEAK CHILDREN}

\begin{abstract}
This article intends to examine the conditions of the city of Rio de Janeiro, regarding the city's health safety or the living and housing conditions of its workers, which helped bringing about the spread of tuberculosis in the end of the $19^{\text {th }}$ century and beginning of the $20^{\text {th }}$ century. Evidencing the high incidence of tuberculosis at this time, it intends to verify the reasons for creating the Brazilian League Against Tuberculosis and its purpose, analyzing its project of assistance to children's health and its intervention to discipline, which resulted in the creation of the Dona Amélia Queen Reformatory.
\end{abstract}

KEY WORDS: Brazilian League against Tuberculosis. History. Assistance to the health of children. Tuberculosis. Rio de Janeiro.

\section{INTRODUÇÃO}

A configuração do espaço urbano deteriorado e o baixo nível das condições de vida da população pobre da cidade, constituída pelo proletariado morando 
em estalagens e cortiços, alguns em péssimas condições higiênicas e outros insaneáveis, facilitavam a disseminação da tuberculose na cidade do Rio de Janeiro, em fins do século XIX e início do XX.

Contudo, a tuberculose não logrou tornar-se uma questão emergente para $\mathrm{o}$ Estado, que, naquele momento, ocupava-se com as doenças epidêmicas, como febre amarela e varíola, que resultavam em grave prejuízo para a economia do país. Dessa forma, as elites médicas e intelectuais do Rio de Janeiro tomaram a si a responsabilidade da questão da tuberculose e criaram, em 4 de agosto de 1900, a Liga Brasileira contra a Tuberculose, como instituição de caráter filantrópico.

O propósito da Liga era a propaganda maciça na imprensa e em conferências públicas para esclarecer a população sobre o caráter curável da doença e a forma de evitá-la. Pretendeu construir sanatórios onde o tuberculoso pudesse buscar a cura pela alimentação, o bom ar e repouso, objetivo este que não chegou a se concretizar pelo seu alto custo, mas criou dispensários onde prestava educação higiênica e assistência médico-social. Em 1905, Alcindo Guanabara, um de seus dirigentes chamou a atenção para a situação das crianças pobres que definhavam em casas superpovoadas, sem ar e sem luz suficientes, tornando-se fortes candidatas à tuberculose. A partir daí, a Liga assumiu a preocupação com a assistência à criança e começou a articular o projeto de um sanatório infantil. Depois de várias negociações, inclusive na busca de recursos, o projeto de sanatório transformou-se na proposta de preventório, lugar onde se acolheria crianças enfraquecidas, mas não tuberculosas. Finalmente, foi instalado na Ilha de Paquetá, em 1927, o Preventório Rainha Dona Amélia. Às crianças aí internadas era prestada assistência material, médica e moral.

$\mathrm{O}$ que se pretende neste artigo é examinar as condições da cidade do Rio de Janeiro, seja no que diz respeito à insalubridade da cidade seja em relação às condições de vida e moradia dos seus trabalhadores, que propiciavam a disseminação da tuberculose no final do século XIX e início do XX. Constatando-se a alta incidência da tuberculose nessa época, pretende-se verificar a motivação e o propósito de criação da Liga Brasileira contra a Tuberculose e analisar o seu projeto de assistência à saúde das crianças e sua intervenção disciplinar, no Preventório Rainha Dona Amélia.

\section{A TUBERCULOSE NA CIDADE DO RIO DE JANEIRO}

Se no início do século XIX, construiu-se uma concepção romântica da tuberculose, reconhecida no campo artístico e literário como a doença da paixão, com a descoberta do agente transmissor da doença -o bacilo de Koch-, em 
1882, e a nova organização social trazida pela industrialização a incidência maior da tuberculose deslocou-se para as classes trabalhadoras. Assim, na virada do século, a tuberculose tornou-se indiscutivelmente uma doença social, de ocorrência e propagação estreitamente vinculadas às condições de vida e trabalho.

Os ricos dispunham de habitações arejadas, com boa iluminação natural, e, quando adoeciam, retiravam-se para um sanatório onde eram submetidos a tratamento higieno-dietético e de repouso, evitando, com isso, a propagação da doença ${ }^{1}$. Na Inglaterra do final do século XVIII, e, um pouco mais tarde, em outros países, os trabalhadores, além de submetidos a fatigantes jornadas de trabalho, aglomeravam-se nas cidades, vivendo promiscuamente em habitações mal iluminadas e pouco arejadas. Corriam, assim, maior risco de adoecer, com a agravante de não terem acesso ao tratamento da época ${ }^{2}$.

$\mathrm{Na}$ cidade do Rio de Janeiro, capital do país, à semelhança de outros países, em fins do século XIX e início do XX, a tuberculose era a maior responsável pela mortalidade

Todos os anos ela eliminava grande contingente da população, só sendo sobrepujada por outra doença nos anos de epidemia ${ }^{3}$.

A alta incidência da tuberculose entre a população pobre do Rio de Janeiro, à essa época, aparece como expressão necessária tanto da configuração de um espaço urbano deteriorado, quanto do baixo nível das condições de vida da população condenada a viver nesse espaço.

1 Sanatórios eram estabelecimentos em que os doentes ficavam internados, submetidos a uma rígida disciplina higiênica, repouso, boa alimentação e vida ao ar livre. A internação, em geral, durava vários anos. Thomas Mann, em seu romance $A$ montanha mágica, retratou o cotidiano da vida no sanatório de Davos, Suíça. No Brasil, essa concepção terapêutica perdurou, com algumas alterações, até a década de 1960, quando começou a ser superada pelos quimioterápicos.

2 Sobre as conseqüências do início da industrialização para as cidades inglesas e suas populações, ver ENGELS, F. (1975), A situação da classe trabalhadora na Inglaterra, Lisboa, Presença.

3 Somente nos anos de epidemia de febre amarela e de varíola é que o coeficiente de mortalidade por essas doenças ultrapassava o índice de mortes por tuberculose. 


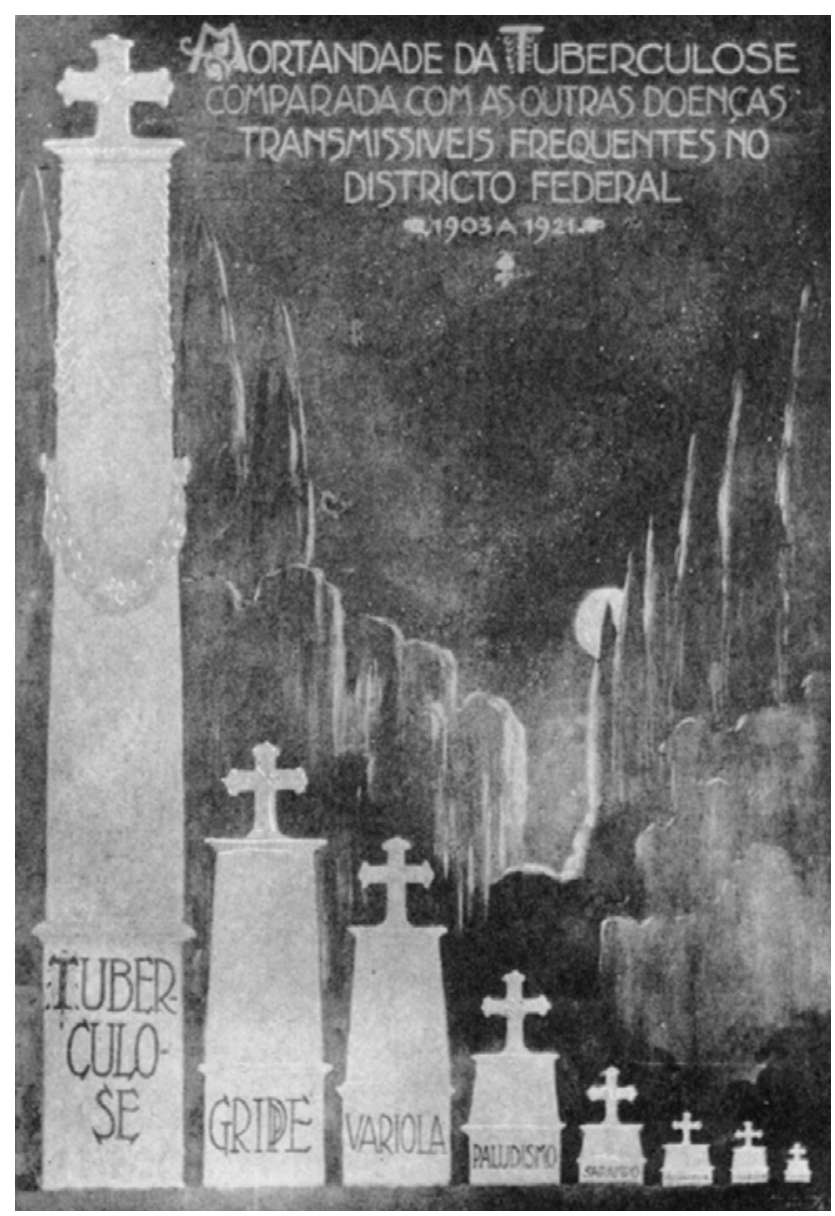

Fig. 1: Representação gráfica do impacto da tuberculose em relação a outras doenças infecciosas no Rio de Janeiro. Acervo Casa de Oswaldo Cruz/Fiocruz.

Em o Rio de Janeiro do Meu Tempo, o cronista Luiz Edmundo (1987: 65) assim descreve a população do Morro do Castelo:

«(...) gente que sai de casa pela madrugada, para exercer empregos em lugares distantes, a lata do almoço embrulhada em papel de jornal; homens de carão pálido e chupado, o cabelo por cortar, a barba por fazer, denunciando moléstia ou penúria extrema; mulheres, das que são o tombo da casa, as burras de trabalho, de ar desalinhado e pobre, as saias de cima, em rodilha, na cintura, úmidas da água dos tan- 
ques onde trabalham o dia inteiro; crianças de ar enfermiço, amarelas e secas, o corpo coberto de feridas [...] umas moçoilas pálidas, cheias de olheiras e sardas, que trabalham cosendo para o Arsenal de Guerra e vivem se queixando de pontadas no lado do pulmão, tonteiras e falta de ar. Pobres raparigas de lábios brancos e sorrisos que fazem mal, com trinta anos e já cheias de melancolia, de rugas e cabelos brancos $[\ldots]\rangle^{4}$.

Essa era a imagem da cidade no seu cotidiano vivido pela população menos favorecida. O Rio de Janeiro nada mais era do que um aglomerado de pequenas vias insalubres, atopetadas de cortiços, onde pululava a massa heterogênea de trabalhadores e miseráveis dividindo o mesmo espaço (Fig. 2).

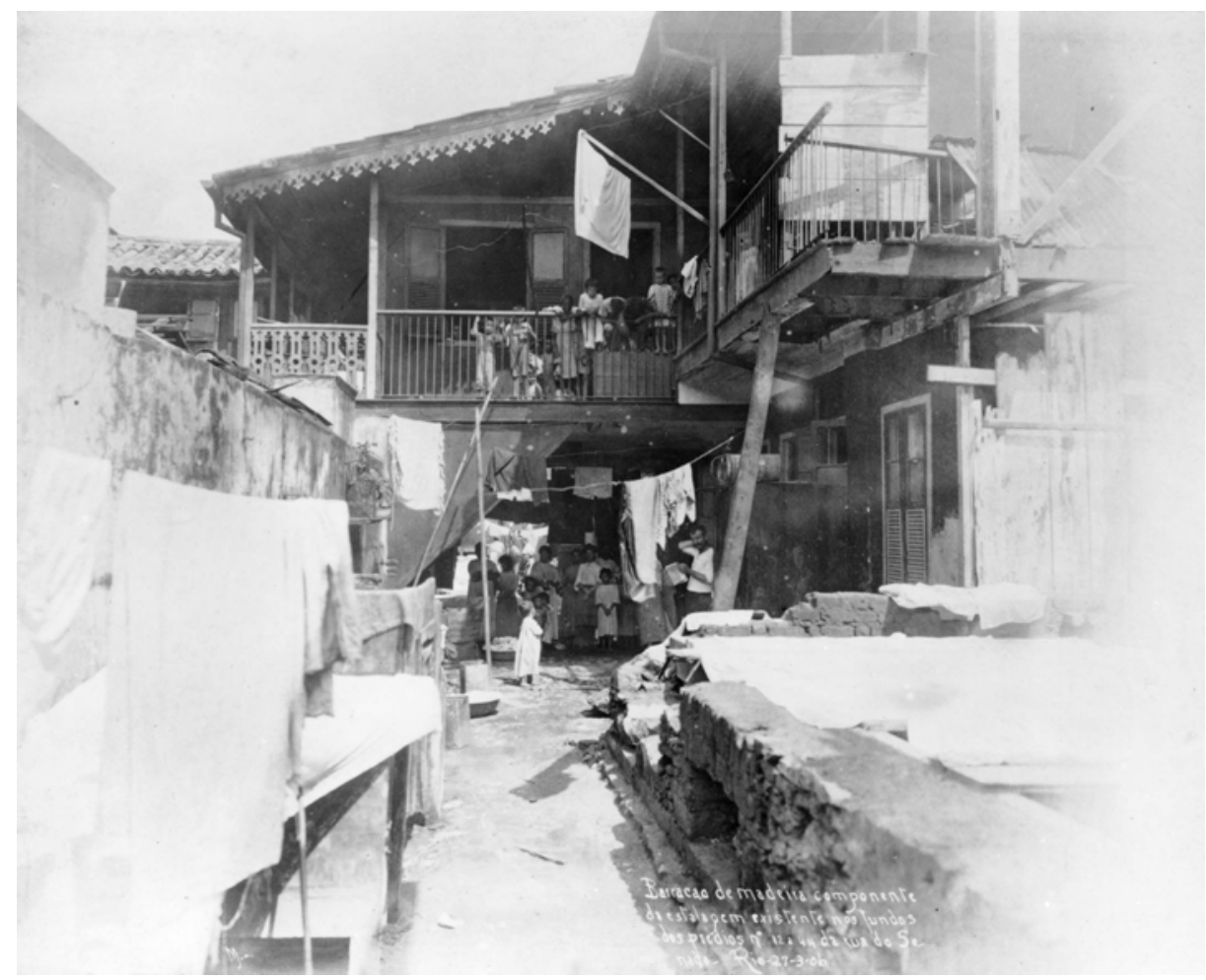

Fig. 2: Cortiço no centro da cidade do Rio de Janeiro, 1906. Acervo Casa de Oswaldo Cruz/Fiocruz.

4 Edmundo, L. (1957), O Rio de Janeiro do meu tempo, Rio de Janeiro, Conquista, $2^{\mathrm{a}}$ ed. 
A insalubridade da cidade contribuía para a disseminação de moléstias que minavam ainda mais as forças daqueles que quase já não as tinham para ganhar o sustento diário. Exceto para poucos, viver na cidade do Rio de Janeiro constituía-se, assim, uma verdadeira prova de resistência física e moral, pois que a grande massa da população aqui concentrada tinha de se defrontar tanto com a escassez de trabalho quanto com as más condições de habitação e alimentação.

No ano de 1895, a incidência maior de óbitos por tuberculose, segundo a circunscrição civil, foi na pretoria de Santana (3,5 por 1000 hab.) e na de São José (3,3 por 1000$)$. Sobre a pretoria de Santana, lê-se no relatório desse mesmo ano de 1895, produzido pela Diretoria Geral de Saúde Pública (DGSP), confirmando o que está dito acima sobre o espaço urbano, que:

«pela sua grande população, em geral constituída pelo proletariado e cheia de estalagens e cortiços, alguns em péssimas condições higiênicas e outros insaneáveis, não admira que forneça todos os anos um grande contingente de óbitos» ${ }^{5}$.

A distribuição da prevalência da tuberculose fazia-se, portanto, comprovadamente, de maneira diferenciada por grupos de população, segundo sua condição de vida e trabalho. Fontenelle, estudando a distribuição da mortalidade por grupos de idade no período 1903-1930, apontou uma curva ascendente no grupo de 20-29 anos e o ápice na faixa etária de 30-39 anos. A maior freqüência de mortalidade por tuberculose dava-se exatamente no período de vida produtiva em que o indivíduo está de uma forma ou de outra vinculado a um tipo de atividade econômica e, portanto, duplamente exposto ao risco do contágio, isto é, na moradia e no trabalho ${ }^{6}$.

No Rio de Janeiro, a partir da segunda metade do século XIX, instalava-se um contingente crescente de imigrantes estrangeiros, além dos ex-escravos oriundos das fazendas de café da região fluminense do Vale do Paraíba, constituindo, assim, uma população altamente diferenciada ${ }^{7}$ : de um lado, os trabalhadores que nem sempre estavam empregados e, quando estavam, rece-

5 DGSP (Direção Geral de Saúde Pública), Relatório da Diretoria Geral de Saúde Pública em 1895. Rio de Janeiro, Imprensa Nacional, 1896, p. 78.

6 Barreto, J.B. (1949), Tratado de higiene, Rio de Janeiro, Departamento de Imprensa Nacional, vol. II, p. 511.

7 Mello, J.M.C. (1987), O capitalismo tardio, São Paulo, Brasiliense, 6a ed. Sobre esse fluxo migratório, ver também: FuRTADO, C. (1986), Formação econômica do Brasil, São Paulo, Cia. Editora Nacional, $21^{\mathrm{a}}$ ed., e SILVA, S. (1976), Expansão cafeeira e origens da indústria no Brasil, São Paulo, Alfa-Ômega. 
biam salário insuficiente para moradia e alimentação adequadas; de outro, os proprietários e os altos representantes do governo, que tinham ao seu dispor, porque podiam comprar, os bens necessários para manter uma condição de vida privilegiada.

A febre amarela e a varíola, cujos surtos epidêmicos tinham freqüência regular na cidade do Rio de Janeiro, estavam na pauta de preocupações do Governo brasileiro, desde a década de 1870 , porque as epidemias resultavam em «grave prejuízo da situação interna e externa do país» ${ }^{8}$. Sucessivamente, os governos republicanos se preocuparam com o saneamento da capital federal, explicitamente motivados pelos interesses do comércio internacional. Mas pelos entraves políticos da descentralização do poder, definida pela Constituição de $1891^{9}$, a sua possibilidade de intervenção era bastante limitada Por outro lado, a economia do município não permitia a realização de projeto de tão alto custo financeiro como reconhecia o próprio governo federal.

A capital federal, ao mesmo tempo em que vivia um processo de expansão urbana, fruto das novas iniciativas empresariais, mostrava-se cada vez mais carente de serviços que atendessem as necessidades de sua população. Especialmente no caso da saúde, a cidade do Rio de Janeiro caracterizava-se pela insalubridade e precaríssimas condições de vida, que vitimizavam a maioria de sua população trabalhadora, sem que houvesse, na passagem do século XIX para o XX, uma ação direta da parte do Estado no sentido de, pelo menos minimizando as trágicas conseqüências da insalubridade e das precárias condições de vida do povo pobre, capacitasse a capital da República a figurar na cena política e econômica internacional como metrópole moderna.

Foi no governo de Rodrigues Alves, em função da expansão econômica da burguesia agro-exportadora e do nascente empresariado fabril, que o projeto político de saneamento da capital veio a se concretizar, considerado «primordial para o reerguimento da vida econômica do país $\rangle^{10}$. Ressaltem-se as condições políticas e técnicas favoráveis à sua viabilização. Os Serviços de Higiene Defensiva da capital passaram, por decreto, à administração do go-

8 BRASIL, Câmara dos Deputados, Mensagens presidenciais (1890-1930), Brasília, DF, Centro de Documentação e Informação: Coordenação de Publicações, 1978, p. 70.

9 A Constituição de 24 de fevereiro de 1891 estabeleceu o regime federativo com completa autonomia para os estados. Em relação à capital da república, especificamente, determinou que caberia à municipalidade do Distrito Federal os serviços concernentes à higiene e polícia sanitária urbana, limpeza da cidade e praias, Hospital São Sebastião, desinfecção e assistência à infância.

10 BRASIL, Câmara dos Deputados, Mensagens presidenciais (1890-1930), Brasília, DF, Centro de Documentação e Informação: Coordenação de Publicações, 1978, p.311. 
verno federal, em julho de 1902, sendo sancionada a transferência em 2 de janeiro de $1903^{11}$. Somaram-se a isso os novos instrumentais técnicos criados com as descobertas de Pasteur no campo da microbiologia e da bacteriologia, que possibilitavam o combate às doenças epidêmicas ${ }^{12}$. $\mathrm{O}$ projeto político de Rodrigues Alves foi concretizado pelo plano urbanístico de Pereira Passos, prefeito do Distrito Federal, e pelo plano sanitário de Oswaldo Cruz, diretor geral de Saúde Pública.

A capital federal transformou-se e adquiriu feição civilizada, moderna e higiênica. Estavam removidos, assim, os obstáculos ao desenvolvimento das atividades comerciais, financeiras e políticas da capital e garantidos o fluxo imigratório e o comércio internacional. Todavia, a modernização da cidade não implicou uma modificação das condições sociais vigentes; ao contrário, só aprofundou as diferenças entre aqueles que desfrutavam de condições de vida privilegiadas e os que lutavam diuturnamente pela sobrevivência.

Com as doenças epidêmicas entrando em franca regressão, a tuberculose começou a ganhar espaço no discurso oficial, que reconhecia o caráter social da doença e admitia a necessidade de um programa sanitário para combatê-la. Aparecia em destaque a questão da habitação relacionada à incidência do mal. Bulhões de Carvalho, médico-demógrafo da Diretoria Geral de Saúde Pública (DGSP), estabelecia essa relação de forma clara:

«A distribuição geográfica da tuberculose na cidade acompanha paralelamente a densidade da população e as precárias condições de habitação. Onde é mais densa a população e onde mais abunda o proletariado é também onde mais avulta o obituário da tuberculose» ${ }^{13}$.

Embora a tuberculose passasse a ter lugar no discurso oficial, foram poucas as tentativas de enfrentamento da doença no âmbito governamental, e mesmo assim sem resultados práticos, nas duas primeiras décadas do século XX.

11 Fontenelle, J.P. (1922), Higiene e saúde pública, Dicionário histórico, geográfico e etnográfico do Brasil, Rio de Janeiro, IHGB, v. 1, p. 430.

A introdução do «modelo pastorano» no Brasil, no final do século XIX, permitiu a utilização de instrumental técnico da microbiologia e bacteriologia em oposição ao antigo «modelo miasmático». Ver, especialmente, PORTOCARRERO, V. (1991), Pasteur e a microbiologia, Revista da Sociedade Brasileira de História da Ciência, 5, 69-81 e BenCHIMOL, J.L. (1990), Pereira Passos, um Haussman tropical - A renovação urbana da cidade do Rio de Janeiro no início do século $X X$, Rio de Janeiro, SMCTT.

13 Carvalho, B. (1904), O Estado Sanitário do Rio de Janeiro em 1903, Brasil-Médico, XVIII (23), p. 15. 


\section{A LigA BRASILEIRA CONTRA A TUBERCULOSE}

As discussões e publicações no meio médico, reclamando medidas sanitárias diante da propagação assustadora da tuberculose, tomaram vulto no final do século XIX e passaram a circular também na imprensa leiga, com o apoio de escritores de idéias liberais sensibilizados com o problema, como Ernesto Senna ${ }^{14}$ e Alcindo Guanabara ${ }^{15}$.

Coerentemente com a concepção liberal de sociedade e de poder público, o Estado não tomaria para si diretamente a tarefa da atenção médica às massas trabalhadoras. $\mathrm{O}$ poder público preferirá financiar as instituições que se proponham a assumir a atenção médica às populações menos favorecidas. Se até os anos 30 o Estado liberal brasileiro pautou sua atuação por uma ingerência limitada no campo da saúde, instituições filantrópicas souberam aproveitar esta característica liberal da ação estatal para influenciar de modo decisivo na formulação de critérios para uma ação filantrópica junto às populações carentes.

Sanglard (2005:166), em sua tese de doutoramento, refere-se ao posicionamento de intelectuais na questão do público e do privado:

«Intelectuais como Monteiro Lobato pregavam a ação da iniciativa privada como a solução para a carência de recursos dos governos latino-americanos. Defendia-se que a iniciativa privada deveria substituir o Estado onde este não conseguia chegar - e quanto mais ações desta natureza, melhor para o país» ${ }^{16}$.

Dessa forma, pode-se depreender que era comum à época, a existência de instituições filantrópicas para dar conta das necessidades da população carente, onde o Estado não assumisse a questão. Pensada como exercício da caridade, a filantropia até o século XVIII era prescrita pela Igreja Católica como imperativo moral a ser seguido pelos que detinham o poder econômico em relação aos menos favorecidos. Tratava-se de converter os ricos à missão da tutela sobre os pobres a fim de que aos primeiros fosse garantido o reino dos Céus ${ }^{17}$.

14 Ernesto Senna (1858-1913), jornalista, historiador e poeta. Trabalhou no Jornal do Povo, Gazeta da Tarde, Gazeta da Noite, Gazetinha, Cidade do Rio e Jornal do Commercio, onde esteve por vinte e sete anos.

15 Alcindo Guanabara (1865-1918), político, escritor, jornalista, defensor dos ideais republicanos, foi deputado constituinte em 1891 e superintendente geral de imigração na Europa em 1893. Trabalhou em vários órgãos da imprensa carioca e integrou a Academia Brasileira de Letras. Senador em 1918, autor de trabalhos e propostas de lei sobre assistência à criança.

16 SANGLARD (2005), Entre os salões e o laboratório: filantropia, mecenato e práticas científicas no Rio de Janeiro, 1920-1940, Doutorado, PPGHCS, COC, Fiocruz.

17 Nascimento, D.R. (2002), Fundação Ataulpho de Paiva: um século de luta, Rio de Janeiro, Quadratim. 
O desenvolvimento progressivo das relações capitalistas de produção e as correlatas transformações nas formas de percepção das contingências humanas conduzirão a uma mudança na visão da pobreza e no papel dos abastados na assistência aos menos favorecidos. O liberalismo, ideologia correspondente à primeira fase da dominação das relações capitalistas de produção da riqueza, ao identificar o trabalho como fonte da riqueza das nações, levará à conclusão da inadequação da idéia da caridade como forma de tutela de ricos sobre pobres. Em seu lugar, construir-se-á o conceito de filantropia que, fundamentado na concepção da assistência «científica» à pobreza, exigirá o concurso de saberes «como a medicina, o direito, a sociologia que (...) [fornecerão] às elites sociais e políticas os instrumentos que [possibilitarão] a classificação das populações» merecedoras de sua atenção ${ }^{18}$. Assim, "surge a filantropia como modelo assistencial repousado no 'cientificismo', [capacitada] a substituir o modelo caritativo» ${ }^{19}$.

No Brasil, a prática caritativa e sua substituta filantrópica aparecem representadas, inicialmente, pelas Santas Casas da Misericórdia. A princípio, instrumentos da política de dominação metropolitana implementada por elementos da elite colonial, as Santas Casas, desde muito cedo, atuarão no sentido da manutenção das condições econômicas e sociais garantidoras dos lucros das elites. Identificadas com o modelo de produção escravista que dominou toda a história do Brasil por mais de três séculos, estas instituições desfrutaram de monopólios e outros privilégios em troca da ação caritativa e, mais tarde, filantrópica em favor das populações pobres, num contexto de ausência do Estado no que diz respeito à assistência dessas mesmas populações.

Com a progressiva e definitiva introdução de relações capitalistas no mundo da produção, isto é, com o crescimento contínuo do emprego de mão de obra assalariada, a partir das últimas décadas do século XIX, e o conseqüente colapso das relações escravistas, além de, no plano político, o Brasil passar da condição de Império à República, marca-se efetivamente o triunfo do pensamento liberal burguês na condução dos negócios públicos e privados.

Os trabalhos que de alguma forma discutem a filantropia remetem à assistência pública e privada como práticas complementares para o enfrentamento das questões sociais advindas da desigualdade ${ }^{20}$. Passa a predominar cada vez mais a opinião de que a assistência aos indigentes era uma obrigação

18 Ibíd., p. 28.

19 Ibíd., p. 29.

20 Ver, por exemplo, PaIVA, A. (1916), Justiça e assistência: Os novos horizontes, Rio de Janeiro, Tipografia do Jornal do Commercio. 
da sociedade a ser cumprida pelo Estado. No contexto da discussão, sobretudo européia, sobre o combate aos problemas sociais para minimizar suas conseqüências, as elites sociais brasileiras também discutem e assumem papéis reformadores.

Em relação à tuberculose, as elites médicas e intelectuais, no Rio de Janeiro, posicionaram-se e atuaram frente ao problema. Como membros da elite social do país, os médicos representavam o pensamento científico, social e político de sua época e sua ideologia baseava-se numa crença inabalável no poder da técnica e da ciência, associada a uma inquestionável atitude cívica.

Aliados aos intelectuais que compartilhavam o mesmo pensamento, esses profissionais voltaram-se para a questão da tuberculose no Rio de Janeiro, a capital federal, por entenderem que os altos índices de mortalidade causados pela doença eram incompatíveis com a instauração da modernidade desejável no país. "A exemplo dos países civilizados», o Brasil tinha que seguir a «grande corrente científica e civilizadora da época» para o «engrandecimento pátrio» ${ }^{21}$.

De início desarticulado, um movimento, alimentado pela própria Academia e por discussões e realizações no exterior, começou a ganhar organicidade no Rio de Janeiro em 1899, quando Cypriano de Freitas, professor de anatomia patológica da Faculdade de Medicina, conclamou a classe médica a criar um órgão específico para combater a tuberculose. Foi o início de um movimento orgânico que levou à fundação da Liga Brasileira contra a Tuberculose ${ }^{22}$.

Aos 4 de agosto de 1900, na Academia Nacional de Medicina, no Rio de Janeiro, realizou-se a sessão solene de instalação da Liga Brasileira contra a Tuberculose. Estiveram presentes, além do arcebispo, que presidiu a sessão, o presidente da República, Campos Sales, alguns ministros de Estado, o diretor geral de Saúde Pública, Nuno de Andrade, e várias figuras de prestígio das áreas política, social e artística. Cypriano de Freitas, ao discursar na ocasião, referiu-se a uma aliança que, pelas figuras que ali compareceram, assim sugeria: «a religião, aliada à ciência e aos altos interesses econômicos e sociais do País, empreende esta Cruzada, de cujos resultados não é lícito duvidar» ${ }^{23}$.

Alcindo Guanabara, também nessa ocasião, em veemente discurso, salientou o «dever e honra da civilização ocidental» de dar combate à tuberculose, apelando ao amor cristão para a concretização dessa tarefa «inadiável» ${ }^{24}$.

\footnotetext{
21 Ver Relatório da Liga Brasileira contra a Tuberculose, 1901, pp. 5-6.

22 Ibíd., p. 5.

23 FreitAS, C. (1900), Liga Brasileira contra a Tuberculose, Brasil-Médico, XIV (37), p. 333.

24 Guanabara, A. (1911), Discursos fora da Câmara, Rio de Janeiro, Livraria Editora.
} 
Estava criada a Liga Brasileira contra a Tuberculose com um discurso em que o móvel era o sentimento humanitário e patriótico, e a ciência era colocada como instrumento para a prática da instituição. A fé na ciência, como diz $\mathrm{Luz}^{25}$, era comum aos médicos e intelectuais da época.

As sucessivas diretorias e conselhos sempre tiveram figuras de prestígio. Os médicos, militantes da clínica tradicional, integravam ao mesmo tempo a Academia Nacional de Medicina e a Faculdade de Medicina, com vozes influentes nos congressos médicos, reivindicando essa influência na política em geral. Outros profissionais não médicos gozavam também de posição social e política privilegiada, ressaltando-se Ataulpho de Paiva, cujo reconhecimento como jurista veio a ser reforçado pelos seus trabalhos sobre assistência pública e privada.

Além de alertar o governo para a responsabilidade de assumir a tuberculose como questão grave e tomar medidas concretas contra mortalidade tão alarmante, a liga procurou criar organismos próprios, considerados fundamentais no combate à doença.

Em seu primeiro estatuto incluiu, no capítulo VII, diretrizes específicas para a criação e organização de um sanatório. Mas, pelo alto custo financeiro, a Liga não chegou a concretizar o projeto do sanatório ${ }^{26}$.

Os dispensários ${ }^{27}$, por serem menos dispendiosos que o sanatório, são incluídos no segundo estatuto da Liga, de 26 de dezembro de 1901, propondose a prestar gratuitamente conselhos e consultas aos enfermos de tuberculose e, quando os recursos da Liga o permitissem, medicamentos gratuitos ${ }^{28}$.

A liga criou seu primeiro dispensário em 26 de janeiro de 1902, que tomou o nome de Dispensário Azevedo Lima. O serviço prestado era basicamente de educação higiênica ${ }^{29}$ e assistência médica, inclusive com atendimento domiciliar, caso o doente não pudesse se locomover até ele. O diagnóstico bacterio-

25 LuZ, M.T. (1982), Medicina e ordem politica brasileira: política e instituições de saúde (1880-1950), Rio de Janeiro, Graal.

26 Ver relatórios da LBCT, principalmente da primeira década.

27 O primeiro dispensário de que se tem notícia foi criado por Robert Philip em Edimburgo, em 1887. Simples e de baixo custo, tinha por função o tratamento de tuberculosos, a descoberta de focos de contágio da doença, a vigilância e educação sanitárias. A idéia de uma instituição dessa natureza não se difundiu imediatamente, só vindo a ser acolhida na Bélgica em 1899, e, mais tarde, na França e Portugal.

28 LBCT. Estatuto da Liga Brasileira contra a Tuberculose, 1901, cap. V, art. 39.

29 A educação higiênica consistia primordialmente no cuidado com o escarro, por ser este o veículo de transmissão do bacilo. Para isso, a liga distribuía aos doentes inscritos no dispensário escarradeiras de bolso e de chão. 
lógico para identificação do bacilo no escarro era também realizado ali. Em 1911, um segundo dispensário, denominado Viscondessa de Moraes, foi criado pela Liga com o objetivo de prestar atendimento à população do bairro de São Cristóvão, refletindo sua preocupação com a instalação de unidades dispensariais em bairros operários.

Até o advento dos quimioterápicos, na década de $1950^{30}$, uma infinidade de medicamentos foi ensaiada no tratamento da tuberculose, como várias especialidades farmacêuticas que continham sais de ouro, particularmente depois de Koch haver demonstrado que sais de ouro impediam o crescimento dos bacilos da doença in vitro ${ }^{31}$. A tuberculina também foi muito usada como terapêutica, principalmente a TOA (Tuberculina Original Antiga), fabricada no Instituto de Manguinhos e fornecida ao dispensário da Liga gratuitamente.

Convencer o público de que a tuberculose era curável e instruí-lo sobre os meios de evitar o contágio eram dois princípios fundamentais da Liga. Nesse sentido, baseou sua estratégia de ação na realização de conferências populares, em fábricas, escolas, quartéis e clubes profissionais, na distribuição de comunicações aos jornais, na produção de circulares e folhetos explicativos, enfim na utilização de todos os meios de convencimento da opinião pública ao seu alcance.

Além disso, publicações especializadas como Brasil-Médico, Revista Médico-Cirúrgica e Syniatrica traziam com freqüência artigos científicos elaborados pela liga, dirigidos exclusivamente à classe médica, como, a partir de 1913, publicou uma revista mensal que servia de instrumento de propaganda popular, saindo regularmente até 1920, sendo substituída, em 1921, por um Almanak. O objetivo era «despertar cuidados, lecionar higiene, vulgarizar conselhos e colaborar com os clínicos na defesa social» ${ }^{32}$.

O patrimônio da liga era constituído pelos recursos advindos das contribuições dos sócios, das doações de particulares, das subvenções dos poderes

30 O primeiro antibiótico de espetacular efeito sobre a tuberculose foi a estreptomicina, descoberta em 1944. Mas o problema não ficou resolvido aí, porque a estreptomicina produziu resistência bacilar. Com a descoberta do ácido paraminossalicílico (PAS), em 1949, e o uso da isoniazida, em 1952, experiências com associação medicamentosa venceram a resistência bacilar. Os estudos experimentais continuaram com a introdução de novos antibióticos, como a rifampicina, o etambutol e a tiacetazona, até chegar ao esquema simplificado que se tem hoje para o tratamento da doença.

31 WaKSMAN, S. (1964), A vitória sobre a tuberculose - de Hipócrates à estreptomicina, São Paulo, Cultrix, trad. Leônidas Hegengerg e Octany Silveira Mota,

32 RiBeIRO, L. (1985), Fundação Ataulpho de Paiva - Liga Brasileira contra a Tuberculose: notas e documentos para a sua história, Rio de Janeiro, s/e. 
públicos, de associações beneficientes, do produto líquido de festividades beneficientes e de contribuições arrecadadas nas fábricas, escolas, igrejas, quartéis, etc. ${ }^{33}$. Mas o que realmente assegurava os recursos da Liga eram as subvenções do Estado.

Ao longo da década de 1920, ganhou maior força a idéia de que a assistência médico-social devia reunir setores públicos e privados com o objetivo comum de melhorar o atendimento hospitalar no país ${ }^{34}$. Um dos principais líderes desse movimento foi Ataulpho de Paiva (1867-1955) que atuou na campanha pela aliança com o Estado e pela sistematização das assistências pública e privada sob a inspeção dele ${ }^{35}$.

\section{O PREVENTÓRIo RAINHA Dona AmÉLIA}

A Liga deu encaminhamento a outro projeto. Alcindo Guanabara ${ }^{36}$ propôs, em 1905, a criação de uma colônia de férias para crianças, justificando:

«Parece-nos que é chegada a ocasião de se atender mais cuidadosamente para a situação das crianças pobres que definham e se estiolam nessas casas superpovoadas, sem ar e sem luz suficientes [...] essas crianças depauperam-se, enfraquecemse e são candidatas à tuberculose $[\ldots] »^{37}$.

A partir dessa proposta, a Liga assumiu a preocupação com a assistência à criança e começou a articular o projeto de um sanatório infantil. Com um recurso financeiro doado pela família real portuguesa, ainda insuficiente para a construção do sanatório, a Liga criou uma caixa própria, alimentada com doações específicas para esse fim. Depois de uma tentativa de construir em um terreno doado à Liga, o projeto do sanatório infantil, ao final, transformou-se em algo mais próximo da idéia de Alcindo Guanabara, isto é, o acolhimento de crianças enfraquecidas, mas não tuberculosas. O Preventório Rainha Dona Amélia $^{38}$, finalmente, foi instalado na Ilha de Paquetá, em 1927.

33 Estatuto da Liga Brasileira contra a Tuberculose, cap. VI, 1900.

34 SANGLARD (2005), pp. 135-136.

35 As décadas de 1910 e 1920 foram marcadas por importantes e diversificados movimentos em favor da elaboração de leis sociais e de previdência no Brasil.

36 Ressalte-se que Alcindo Guanabara também atuava na assistência à criança. Produziu vários artigos e projetos de lei sobre o assunto.

37 Relatório da Liga Brasileira contra a Tuberculose, 1905, p. 39.

$38 \mathrm{O}$ nome do preventório foi motivado pela doação financeira da família real portuguesa. 


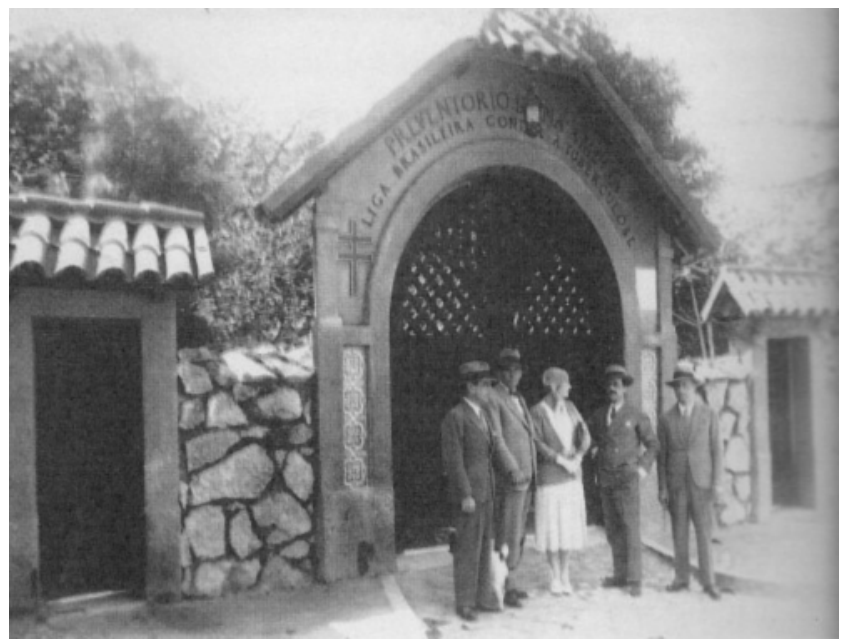

Fig. 3: Portão principal do Preventório Rainha Dona Amélia, em Paquetá. Acervo FAP.

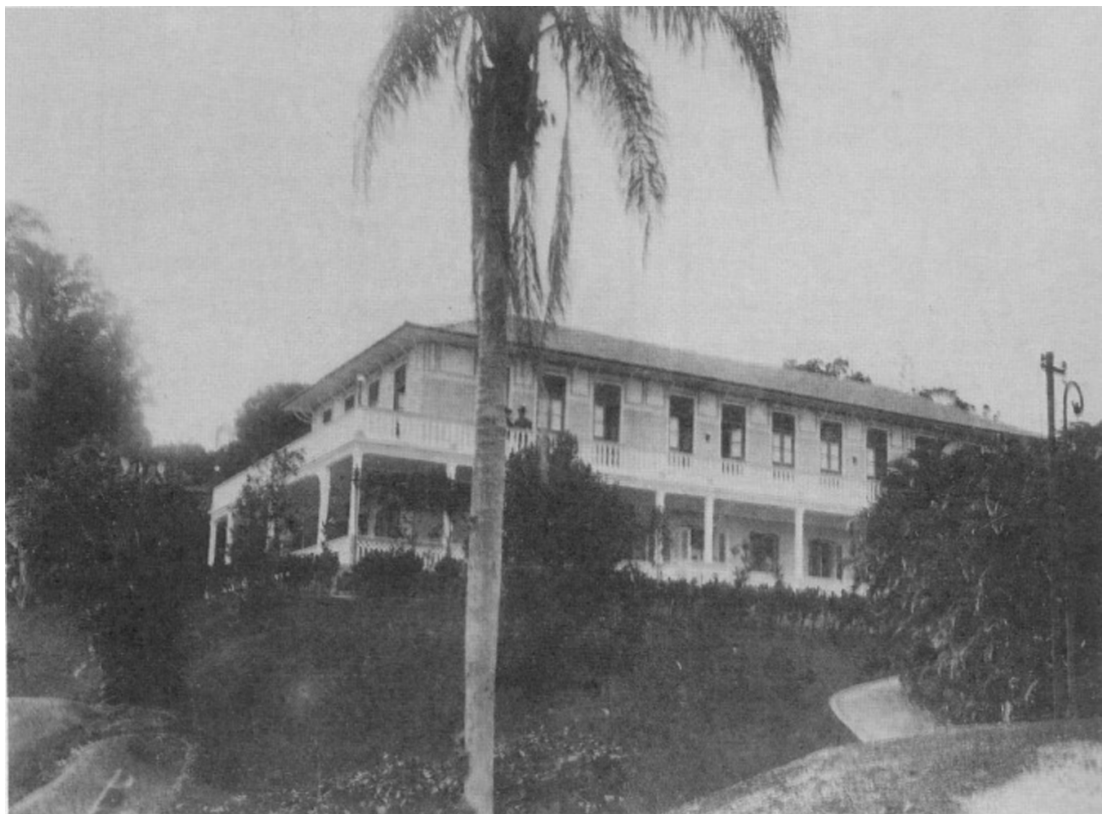

Fig. 4: Prédio do Preventório Rainha Dona Amélia, em Paquetá. Acervo FAP. 
A chácara na Ilha de Paquetá, de propriedade de Gustavo Riedel, estava à venda e foi oferecida, preferencialmente, à Liga para ali instalar o seu preventório, tendo sido negociado um preço bastante acessível. Dessa forma, a compra foi efetivada aos nove de fevereiro de 1924, e logo foram iniciadas as obras de adaptação necessárias ao funcionamento do preventório.

Outra decisão tomada foi em relação à administração do preventório, que recaiu sobre a Congregação das Irmãs de Caridade de Nossa Senhora das Mercês, com sede na Espanha. Por vias diplomáticas, foi estabelecido um contrato com as irmãs mercedárias para dirigirem, administrarem e cuidarem do Preventório Rainha Dona Amélia, em fins de março de 1926. Antes mesmo de as obras estarem prontas, aqui chegaram seis congregadas.

Ataulpho de Paiva, presidente da Liga, nomeou para diretor técnico do preventório o Dr. Almir Madeira, na época diretor de Higiene de Niterói e autor de vários trabalhos sobre colônia de férias e, para o cargo de diretor geral do preventório, o Dr. João de Oliveira Pereira Junior, secretário geral da Liga $^{39}$. Em reunião do Conselho Deliberativo da Liga, aos 27 de junho de 1927, Ataulpho de Paiva comunicou que, «sem bulha nem matinada», já havia 49 crianças internas no preventório.

As atitudes de Ataulpho de Paiva não eram comumente pautadas por ausência de «bulha e matinada». Em geral, ele usava todos os recursos possíveis para divulgar suas ações, principalmente, no que dizia respeito à Liga. Provavelmente, os recursos foram esgotados com a construção do preventório, hipótese corroborada com a ebulição ocorrida na ocasião da inauguração de outro preventório da Liga, o da Ilha Grande, quando em 9 de janeiro de 1930 depois de uma missa na Igreja de São Sebastião — antiga Catedral do Rio de Janeiro—, 150 meninos, de várias instituições de caridade ou de famílias pobres, encaminharam-se para as docas do Lloyd e seguiram para a Ilha Grande, onde ficaram até o dia 14 de março. No dia 20 de março de 1930, foi a vez das meninas, que regressaram em $1^{\circ}$ de junho, cuja experiência, embora altamente produtiva, não pôde ser repetida não só pelas dificuldades da Liga na manutenção de dois preventórios como também, e a nosso ver principalmente, por mudanças na condução política do país.

39 Ata de reunião da diretoria da Liga Brasileira contra a Tuberculose, arquivo FAP. 


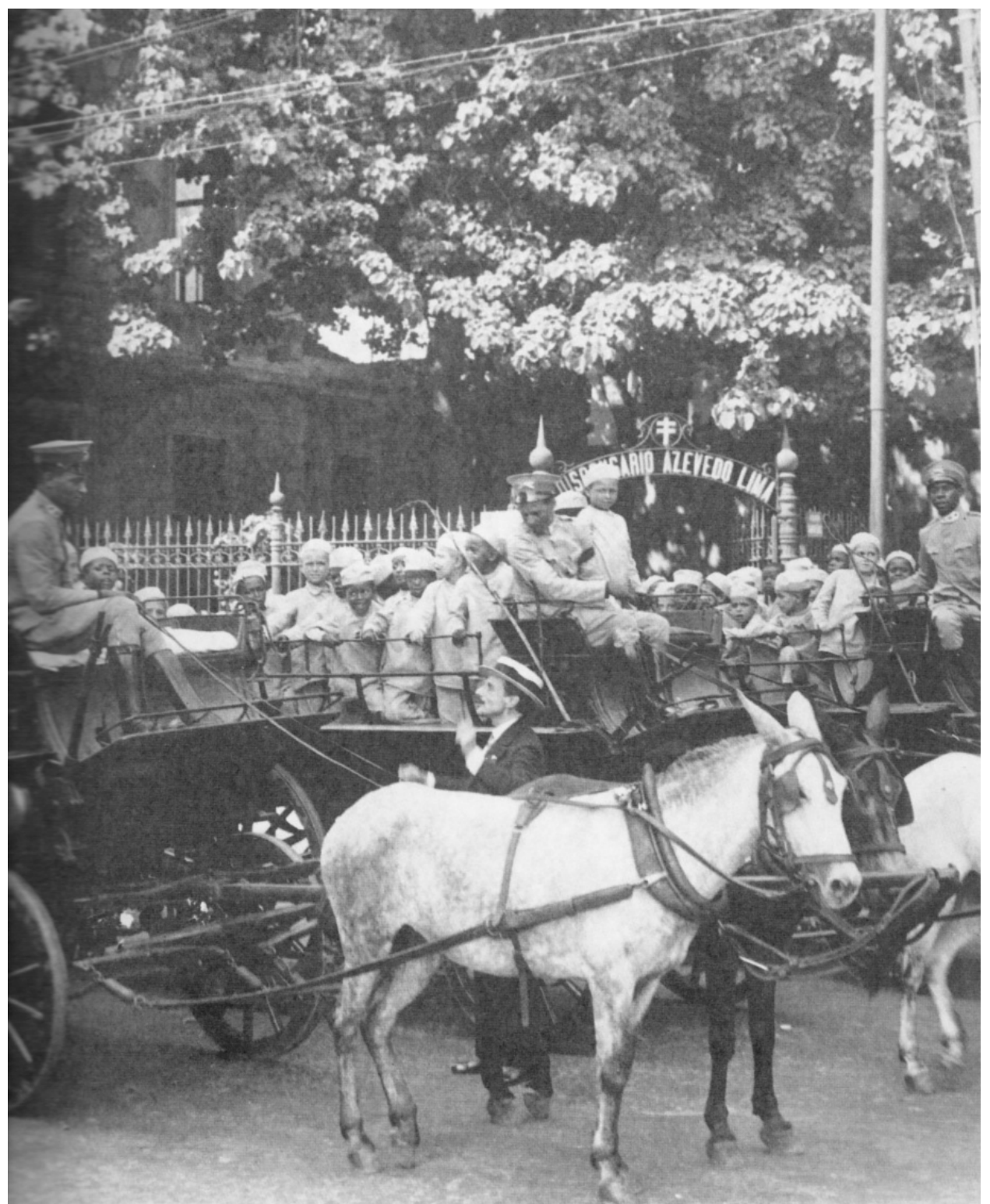

Fig. 5: Ataulpho de Paiva, na porta do Dispensário Azevedo Lima, entre os coches que transportariam as crianças até o cais de embarque para o Preventório da Ilha Grande, 9 de janeiro de 1930. Acervo FAP. 
A Liga, aos poucos, investiu no Preventório Rainha Dona Amélia e foi comprando as chácaras vizinhas onde construiu novos pavilhões e com isso aumentou a sua capacidade de assistência aos menores. Convênios foram assinados com o Departamento Nacional de Saúde e com a Prefeitura do Distrito Federal, que repassavam à Liga recursos para custeio da internação de menores no preventório.

Assim, a receita do preventório sempre foi constituída de parte dos recursos próprios da Liga, parte de verbas de convênio com órgãos públicos e parte de doações, do comércio e de outras instituições privadas. Ataulpho de Paiva sempre convidava pessoas de prestígio social ou político, entidades beneméritas e as autoridades do governo para visitarem o preventório de Paquetá.

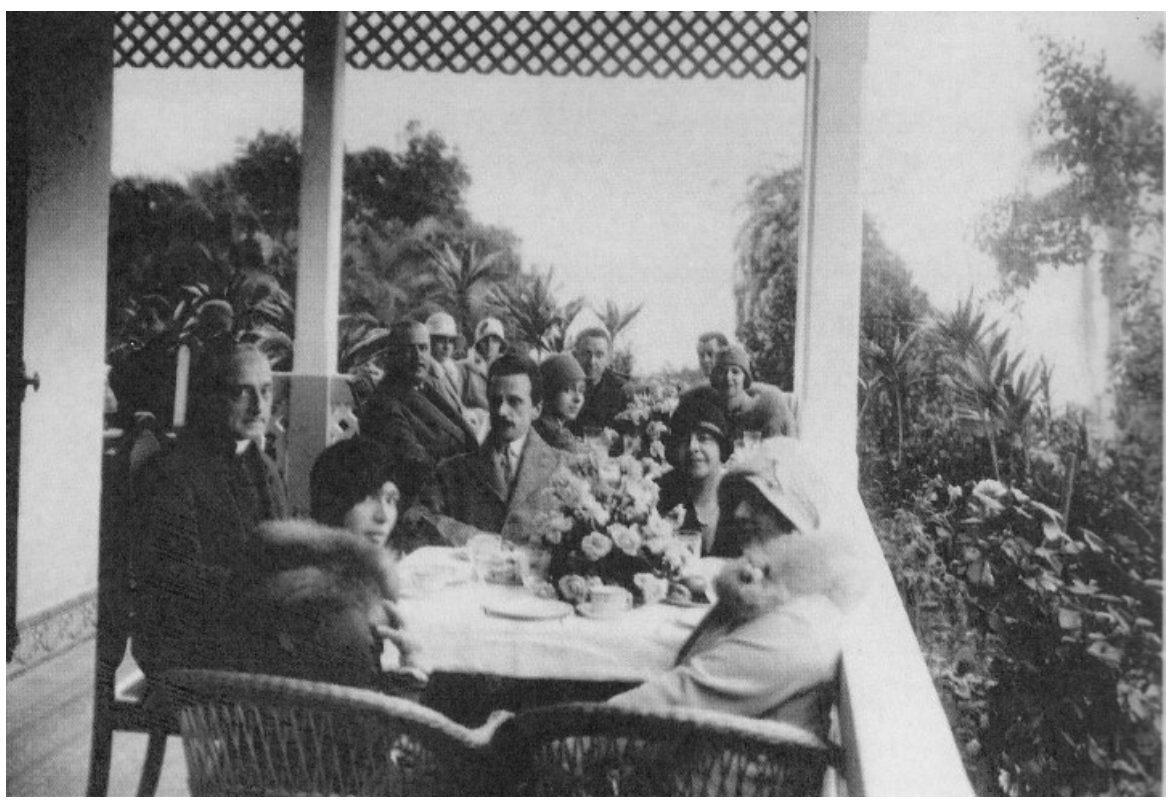

Fig. 6: Ataulpho de Paiva, sentado de frente na primeira mesa, em chá oferecido aos membros da Associação Comercial do Rio de Janeiro, na varanda do Preventório Rainha Dona Amélia, década de 1930. Acervo FAP.

Essa era uma das formas de divulgar o trabalho da Liga e de manter, por outro lado, as doações e convênios que sustentavam parcialmente o preventório. Nessas ocasiões, as crianças faziam demonstrações para as visitas de suas boas condições físicas, sugerindo o sucesso do projeto do Preventório. 


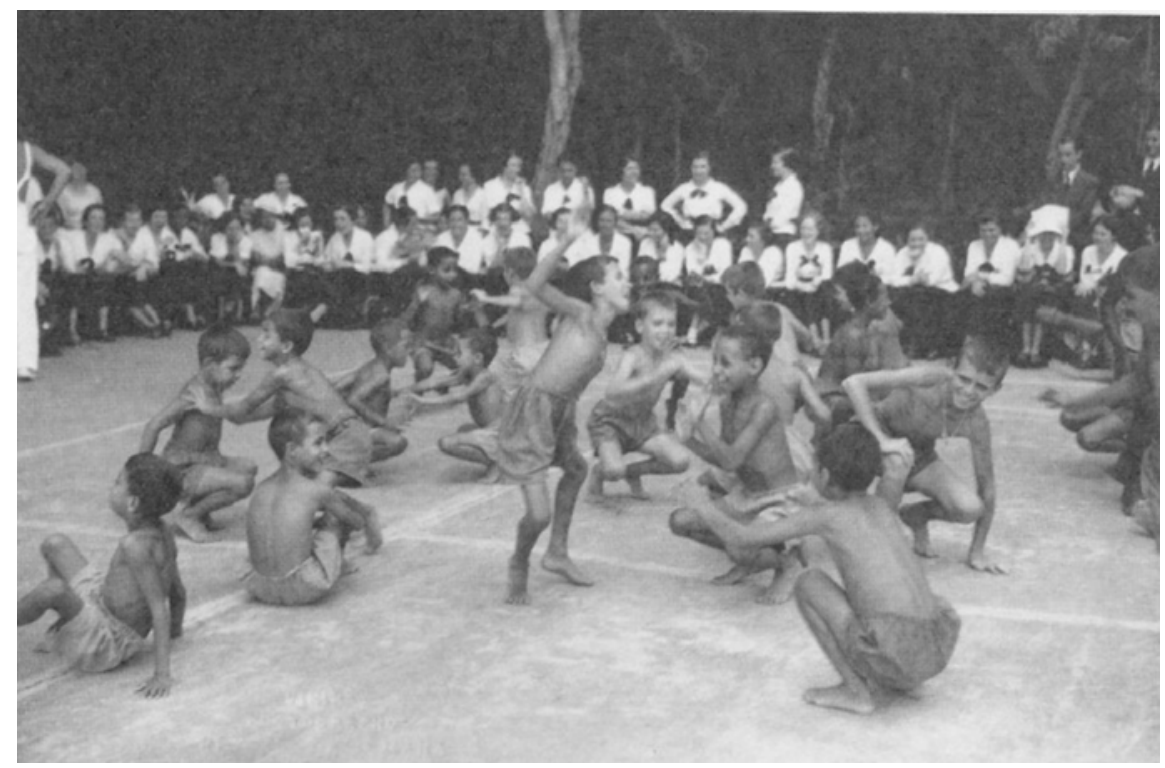

Fig. 7: Crianças internas do Preventório Rainha Dona Amélia fazendo ginástica para um grupo de visitantes, década de 1930. Acervo FAP.

Por alguns anos, o número de crianças internas no preventório chegou próximo de 200. As crianças eram encaminhadas pelos órgãos públicos de assistência infantil ou a partir de pedidos feitos diretamente a Ataulpho de Paiva, vindos da família ou de «padrinhos» da criança. No Preventório, que tinha excelentes instalações tanto nos dormitórios quanto na cozinha, as crianças eram submetidas a uma rígida disciplina de horários e de atividades. Sob os cuidados das freiras da Congregação das Irmãs de Caridade de Nossa Senhora das Mercês, as crianças passavam um período inicial sem o contato com a família, para que pudessem se fortalecer fisicamente. Depois desse período, as visitas de membros da família eram estimuladas, desde que não fossem doentes de tuberculose.

O tempo de internação das crianças era o tempo de sobrevida do pai ou da mãe doente. Mas a tuberculose, como doença insidiosa, crônica, pode fazer com que o doente tenha uma longa sobrevida. E, na maioria dos casos, assim aconteceu: as crianças entravam para o preventório com idade em torno de 2 anos e lá ficavam por 7 ou mesmo 10 anos, em geral, por óbito do familiar tuberculoso.

Tão logo as crianças chegavam no Preventório, eram examinadas pelo pediatra e colocadas em quarentena no Pavilhão de Isolamento. Na opinião de 
Raquel ${ }^{40}$, hoje com 71 anos de idade, que foi interna no Preventório por oito anos, «o único senão no paraíso que era o preventório, era a D. Laura, responsável pelo Pavilhão de Isolamento». Marina ${ }^{41}$, hoje com 74 anos de idade, por sua vez, não compartilha da opinião de Raquel quanto ao fato de o preventório ser um paraíso, mas considera que «alguma coisa boa havia de ter, porque ninguém deu pra coisa ruim». Já em relação ao isolamento, concorda ter sido uma experiência muito ruim. As crianças eram isoladas ao chegarem e toda vez que contraíam uma doença transmissível, significando sempre uma separação: da família ao chegarem e do coletivo das meninas ao adoecerem.

A vida numa instituição está longe de ser equivalente à vida de uma criança em um ambiente livre. Como ressalta Goffman, «o aspecto central das instituições totais pode ser descrito como a ruptura das barreiras que comumente separam as três esferas da vida: dormir, brincar e trabalhar. Elas são realizados no mesmo local e sob uma única autoridade» ${ }^{42}$.

No preventório, as crianças possuíam horários determinados para realizarem as atividades e todas eram coletivas, ou seja, hora de acordar, hora de almoçar, hora de descansar, hora de tomar banho, hora de rezar, toda a rotina diária era regulada por horário e realizada coletivamente.

Sem dúvida, o preventório podia ser considerado uma instituição total, conforme conceituação de Goffman ${ }^{43}$, tendo em vista suas características massificadoras. A rotina institucional com horários inflexíveis tende a apagar os desejos e individualidades dos internos e, como diz Goffman, «cada fase da atividade diária é realizada na companhia imediata de um grupo relativamente grande de outras pessoas, todas elas tratadas da mesma forma e obrigadas a fazer as mesmas coisas em conjunto» ${ }^{44}$.

40 Entrevista realizada, em 3 de agosto de 2007, com uma ex-interna do Preventório para fins desse artigo. A fita gravada encontra-se no Acervo da Casa de Oswaldo Cruz/Fiocruz. O nome utilizado no texto é fictício.

41 Entrevista realizada em 7 de agosto de 2007, com uma ex-interna do Preventório para fins desse artigo. A fita gravada encontra-se no Acervo da Casa de Oswaldo Cruz/Fiocruz. O nome utilizado no texto é fictício. Marina entrou para o Preventório com menos de 2 anos e saiu aos 10 anos de idade.

42 Goffman, E. (2007), Manicômios, Prisões e Conventos, São Paulo, Perspectiva, $7^{\mathrm{a}}$ edição, p. 17.

43 Goffman define «instituição total como um local de residência e trabalho onde grande número de indivíduos com situação semelhante, separados da sociedade mais ampla por considerável período de tempo, levam uma vida fechada e formalmente administrada». GOFFMAN (2007), p. 11.

$44 \operatorname{GofFMAN}(2007)$, p. 18. 
Sobre a hora do descanso, após o almoço, ambas as entrevistadas lembram bem: «todas as meninas tinham que deitar numa esteira, ficar bem retas e com a roupa bem esticada». Quem assim não o fizesse apanhava de vara da Irmã Dolores ou ia para o dormitório de castigo. Isso significava também ficar sem comer o lanche, como ressalta Marina.

Segundo Raquel e Marina, não só horários, mas várias normas tinham que ser cumpridas por todas, como por exemplo, a roupa das meninas, que elas próprias lavavam, tinha que ser pendurada pelo avesso. Os castigos que eram aplicados a qualquer descumprimento das normas, em geral, eram «ficar de cara para a parede e sem comida».

Em relação aos meninos lá internados, as meninas os encontravam em todas as atividades, mas «não podiam se misturar». Marina comenta que «as Irmãs do preventório tinham a mentalidade muito arcaica, pois as meninas que engravidavam ficavam isoladas, sugerindo que sexualidade e sexo eram tabus.

Em que pese duas pequenas cicatrizes gravadas no corpo da Raquel —ambas causadas por castigos infligidos pela Irmã Dolores - ela afirma enfaticamente que «o preventório era o céu», que o período que passou lá foi o melhor de sua vida. «Elas tinham ocupação o dia inteiro, brincavam muito e as visitas de Ataulpho de Paiva, que eram freqüentes, eram uma festa». Ele aparecia sempre impecavelmente vestido de chapéu e terno de linho branco.

Raquel diz ainda que sentia falta dos pais diariamente, mas tinha o amor e o carinho das Irmãs. Afirma que recebia visita da família toda semana, mas ao mesmo tempo, só soube da internação de sua irmã mais nova, depois que a irmã já estava lá. Marina, por sua vez, diz que chegava a sentir revolta pela ausência da família. Sua mãe era falecida e seu pai tuberculoso. Assim, o pai de uma outra interna, ao visitar a filha, visitava também outras quatro meninas, dentre elas a Marina e sua irmã Dalva.

Como foi dito anteriormente, o tempo de internação das crianças correspondia à sobrevida do familiar tuberculoso, assim, com a morte do pai de Marina e a morte da mãe de Raquel, elas tiveram que deixar o preventório, mas foram direto para outro internato. Contudo, os laços afetivos criados no preventório elas mantiveram ao longo da vida, seja com outras meninas seja com algumas das Irmãs.

Mas não só os laços afetivos. Na narrativa de Raquel, por exemplo, a questão de limpeza é reiterativa. Refere-se ao preventório como «um lugar muito limpo». Lembra do médico, das freiras e dos funcionários como «pessoas bem postas e limpas». Ao comparar o internato com o preventório, a limpeza aparece como o diferencial principal entre um e outro. A forma como 
Raquel lida com a questão da limpeza hoje $\mathrm{e}^{45}$, provavelmente tem a ver com a experiência vivida no preventório.

O advento dos quimioterápicos, na década de 1950, que se mostraram eficazes no tratamento da tuberculose, possibilitaram uma mudança na política de controle da doença. Assim, a partir da década de 1960, a concepção terapêutica sanatorial foi superada pelos quimioterápicos e o tratamento da tuberculose passou a ser ambulatorial. Da mesma forma, a finalidade do preventório perdeu seu sentido, pois nessa nova concepção, os filhos de tuberculosos não precisavam mais ser separados dos pais que estivessem doentes.

\section{COMENTÁRIOS FINAIS}

Como instituição filantrópica que agia em nome da ciência e movida por sentimentos humanitários e patrióticos (conforme o discurso de seus representantes), a liga acabava também por servir ideologicamente ao Estado liberal já que este não tinha um projeto de intervenção social, limitando-se ao papel de financiador das iniciativas da sociedade civil.

Se na década de 1910 e 1920 ocorreram importantes e diversificados movimentos em favor da elaboração de leis sociais e de previdência no Brasil, na década de 1930, o Governo de Getúlio Vargas, colocado no poder pela chamada Revolução de 30, teve no reconhecimento e no enfrentamento da questão social no Brasil uma justificativa ideológica para a construção de um Estado forte que interviesse em todos os espaços sociais, econômicos e políticos do país. Os intelectuais que compartilhavam desse ideário, entendiam que era necessário «promover a superação do estado de necessidade em que vivia o povo brasileiro, enfrentando a realidade política e econômica da pobreza das mas$\operatorname{sas}{ }^{46}$. Assim, o Estado passou, ele próprio, a implementar as políticas sociais.

A Liga por seu lado se inscreveu na área da produção: em 30 de dezembro de 1930, inaugurou seu Laboratório de Preparo do BCG. Desde então, a Liga passou a ser a única produtora de BCG no Brasil. Arlindo de Assis, à época, transferiu-se do Instituto Vital Brasil para a Liga e nesta desenvolvia estudos que visavam a um rendimento cada vez maior da vacina.

45 Para entrar na sua casa, a pessoa tem que tirar os sapatos e deixá-los na porta e a seguir lavar as mãos. Ao sair, depois de calçar os sapatos ela lhe entrega uma toalha de papel com álcool para passar nas mãos. É um ritual em relação ao qual ela é inflexível.

46 GoMES, Â.C. (1988), A invenção do trabalhismo, São Paulo, Ed. Vértice, Editora Revista dos Tribunais/Rio de Janeiro: IUPERJ, p. 214. 
O projeto do Preventório Rainha Dona Amélia respondia à concepção terapêutica da tuberculose à época: segregar o doente em sanatórios e seus filhos em preventórios, com o intuito de controlar a disseminação da doença e na tentativa de cura da doença pela disciplina e educação higiênica.

Com as mudanças na condução política do Estado brasileiro e também com o advento dos quimioterápicos, na década de 1950, que tornou sem sentido o isolamento, pois a cura e a profilaxia da tuberculose passou a se realizar com a administração de medicamentos, o preventório foi se adaptando às mudanças, preservando, contudo, a essência de seu objetivo inicial quer seja dar assistência a menores, principalmente aos mais necessitados e se tornou escola ora em nível de jardim de infância ora de ensino fundamental para crianças na faixa etária de 6-12 anos, oriundas de famílias pobres ${ }^{47}$.

O Preventório Rainha Dona Amélia continuou sendo a grande obra de assistência da Liga Brasileira contra a Tuberculose, hoje Fundação Ataulpho de Paiva, o que a legitima até hoje como instituição filantrópica.

Fecha de recepción: 18 de septiembre de 2007.

Fecha de aceptación: 21 de abril de 2008.

47 Relatório anual da Fundação Ataulpho de Paiva, referente ao ano de 1980, Arquivo FAP. 